\title{
Project ART-ED: alcohol reduction and HIV testing in the emergency department
}

\author{
E Jennifer Edelman ${ }^{1 *}$, An Dinh², Lucian Radu-Radulescư ${ }^{3}$, Bonnie Lurie ${ }^{2}$, Jeanette Tetrault ${ }^{2}$, Gail D'Onofrio $^{2}$, \\ David Fiellin², Lynn Fiellin² \\ From International Network on Brief Interventions for Alcohol and Other Drugs (INEBRIA) Meeting 2011 \\ Boston, MA, USA. 21-23 September 2011
}

Unhealthy alcohol use and HIV risk often co-occur. To intervene on this association, we are conducting a pilot study to determine the feasibility and impact of providing brief alcohol- and sexual-risk reduction counseling with rapid HIV testing in a large urban emergency department (ED). We are recruiting ED patients aged 18-40 years who 1) meet National Institute on Alcohol Abuse and Alcoholism criteria for at-risk drinking, 2) have $>1$ sexual-risk behavior, 3) have negative or unknown HIV status, and 4) are willing to undergo HIV testing. We are conducting a brief, manual-guided intervention combining an alcoholand sexual-risk reduction counseling session with rapid HIV testing followed by a booster telephone call at two weeks. At baseline and eight weeks, we assess alcohol consumption with the Timeline Follow-Back for alcohol consumption and a modified HIV Risk Behavior Scale to characterize sexual risk behaviors. Statistical analyses include Wilcoxon Signed Rank test, McNemar test, and two-way ANOVA. Of the 82 participants enrolled to date, $60 \%$ are male, the mean age is 25 years, $63 \%$ are white, $83 \%$ are unmarried, $59 \%$ are college-educated, $41 \%$ are without primary care, and 79\% have an AUDIT score of $>8$. All tested HIV negative. Among the 62 with follow-up data so far, alcohol consumption decreased with fewer average weekly drinks $(25.5$ versus $10.4, \mathrm{p}<0.0001)$ and binge drinking episodes $(2.03$ versus $0.99, \mathrm{p}<0.0001)$. This decrease was greater in men than women $(\mathrm{p}<$ 0.0002). Post-intervention, participants endorsed increased condom use (median change $=3$ points on a 5 -point scale, $\mathrm{W}=275, \mathrm{p}<0.0001)$ and decreased episodes of sex while intoxicated $(\mathrm{RR}=0.14, \mathrm{p}<0.0001)$. Mean intervention duration was 44 minutes. Preliminary analyses demonstrate that a brief intervention combining alcohol- and

${ }^{1}$ Veterans Affairs Connecticut Healthcare System Clinical Scholar's Program and Yale University, New Haven, CT, USA

Full list of author information is available at the end of the article sexual-risk reduction counseling with rapid HIV testing in the ED is feasible and effective for reducing alcohol use and HIV risk behaviors among young unhealthy drinkers.

\section{Author details \\ 'Veterans Affairs Connecticut Healthcare System Clinical Scholar's Program and Yale University, New Haven, CT, USA. ${ }^{2}$ Yale University School of Medicine, New Haven, CT, USA. ${ }^{3}$ Substance Abuse Treatment Program, Veterans Affairs Central Western Massachusetts, Pittsfield, MA, USA.}

Published: 9 October 2012

doi:10.1186/1940-0640-7-S1-A35

Cite this article as: Edelman et al: Project ART-ED: alcohol reduction and HIV testing in the emergency department. Addiction Science \& Clinical Practice 2012 7(Suppl 1):A35.

Submit your next manuscript to BioMed Central and take full advantage of:

- Convenient online submission

- Thorough peer review

- No space constraints or color figure charges

- Immediate publication on acceptance

- Inclusion in PubMed, CAS, Scopus and Google Scholar

- Research which is freely available for redistribution

Submit your manuscript at www.biomedcentral.com/submit

\section{() Biomed Central}

